\title{
A double blinded randomized controlled trial to compare Ormeloxifene and Norethisterone in the treatment of Dysfunctional Uterine Bleeding
}

\author{
Dr. Chitrangada MS, Dr. Satyajeet Kumar Singh MSDr Prof Subrata Nag
}

\begin{abstract}
Aims: To compare the safety and efficacy of ormeloxifene and norethisterone in treatment of dysfunctional uterine bleeding as measured by decrease in menstrual blood loss using pictorial blood assessment chart. To assess the percentage change in haemoglobin and endometrial thickness before and after treatment. To assess the subjective improvement in life style as evaluated by a five point Likert scale.

Methods: A double blinded randomized control trial was conducted on patients attending gynaecology OPD with complaints of menorrhagia with following inclusion criteria women between 18 and 51 years of age, absence of coagulopathies and any pelvic pathology, not taking any drug affecting menstruation, no hormonal therapy in previous three months and normal renal function.

Findings and Interpretation: The menstrual blood loss was observed to decrease by $19.31 \%$ at end of two months, $30.74 \%$ at the end of four months and $43.25 \%$ at end of six months in case of norethisterone and $20.72 \%$ at the end of two months, $43.37 \%$ at end of four months and $59.50 \%$ at the end of six months in case of Ormeloxifene. There was an increase in haemoglobin percentage in both the groups and it was significantly better in case of Ormeloxifene. PBAC score and endometrial thickness improvement was better in case of ormeloxifene compared to norethisterone. The side effects were similar in both the cases except for follicular cyst which was seen in Ormeloxifene group.
\end{abstract}

\section{Introduction}

A woman can expect roughly 400 menstrual cycles during her reproductive lifespan, and it is estimated that up to $20 \%$ of women will have excessive menstrual blood loss. Although age of menopause has remained the same over this century, the magnitude of menstrual disorders has increased, likely because of shortened breast-feeding intervals, fewer pregnancies per woman, higher frequency of permanent sterilization, and later age of conception. Dysfunctional uterine bleeding is a diagnosis of exclusion when organic, systemic and pelvic pathology all have been ruled out. Once a diagnosis has been reached with the aid of history, examination, haematological and endocrine investigations, and dilatation and curettage when appropriate, medical treatment is the usual first line approach. The treatment options for dysfunctional uterine bleeding are diverse, which can be finally tailored to cater the needs of patients of different socioeconomic background, different age groups and different reproductive needs. Treatment options range from offering medical measures such as cyclooxygenase inhibitors, tranexamic acid, hormonal agents and in cases not managed by medical therapy offering surgical management. Trials comparing the various modalities have flooded the literature but ambiguity still exists.

Norethisterone is still the most frequently prescribed drug for dysfunctional uterine bleeding serving $38 \%$ of the patient population the reason being cost effectiveness and absence of side effects. Ormeloxifene (also known as centchroman) is one of the selective estrogen receptor modulators used primarily as a contraceptive, but it is also effective in dysfunctional uterine bleeding. We undertook the study to compare the safety and efficacy of the two drugs in dysfunctional uterine bleeding.

\section{Methods}

A prospective double blinded randomized control trial was conducted between July 2011 to June 2012 on patients who attended the obstetrics and gynaecology department of R.G Kar Medical College with heavy menstrual bleeding. The study was performed in accordance with the ethical principles and was approved by the institutional ethics review board. Each participant provided a written informed consent.

The inclusion criteria include women between 18 and 51 years of age, absence of coagulopathies, absence of any pelvic pathology, not taking any drug affecting menstrual blood loss, no hormonal therapy in previous three months and normal renal function. Those with pathology such as sub mucous fibroid, polyp, adnexal mass, active bleeding necessitating emergency treatment, renal or hepatic dysfunction, history of malignancy, presence of endocrinopathies and abnormal pap smear were excluded from the study. 
Initial evaluation included detailed medical, obstetric and menstrual history taking, assessment of blood loss using pictorial blood assessment chart, investigations which included haematological evaluation, thyroid profile and transvaginal ultrasonography. After the diagnosis of dysfunctional functional uterine bleeding was made patients were randomized to either ormeloxifene or norethisterone using random number tables. Ormeloxifene was given at a dose of $60 \mathrm{mg}$ twice a week for 12 weeks and then once a week for next 4 weeks. Norethisterone was given at a dose of $5 \mathrm{mg}$ three times a day for 21 days a month for four consecutive cycles. The patients were followed at two months and four months during the therapy and six months after stoppage of therapy.

The investigations were repeated at two months four months and six months. The efficacy was measured in terms of decrease in menstrual blood loss as assessed by pictorial blood assessment chart. The safety was measured in terms of side effects experienced in two groups. The changes in haemoglobin and endometrial thickness before and after treatment were assessed. The subjective improvement was assessed by five point Likert scale.

\section{Results}

100 patients were recruited into the study of which 50 were randomized to receive ormeloxifene and 50 norethisterone. There was no significant difference between two treatment groups in age, parity, duration of menorrhagia and menstrual history. The variables used to assess efficacy were also comparable at baseline.

Statistics - Demographic Profile

\begin{tabular}{|lccc|}
\hline Characteristics & Ormeloxifene & Norethisterone & $\begin{array}{l}\text { P- } \\
\text { Value }\end{array}$ \\
\hline Parity & $40.18 \pm 4.52$ & $40.2 \pm 4.56$ & 0.994 \\
\hline $\begin{array}{l}\text { Years of } \\
\text { Education }\end{array}$ & $2.8 \pm 0.85$ & $2.8 \pm 0.78$ & 0.991 \\
\hline $\begin{array}{l}\text { Pre Treatment } \\
\text { Haemoglobin } \\
\text { Value }\end{array}$ & $7.27 \pm 0.196$ & $7.42 \pm .244$ & 0.643 \\
\hline $\begin{array}{l}\text { Pre Treatment } \\
\text { PBAC Score }\end{array}$ & $196.46 \pm 7.48$ & $186.35 \pm 7.50$ & 0.121 \\
\hline $\begin{array}{l}\text { Pre Treatment } \\
\text { Endometrial } \\
\text { Thickness }\end{array}$ & $5.49 \pm 0.26$ & $5.08 \pm 0.17$ & 0.111 \\
\hline
\end{tabular}

Table-1 Demographic profile

The average haemoglobin level found to be $7.27 \mathrm{gm} / \mathrm{dl}$ in the Ormeloxifene group at beginning of the study as compared to 7.42 Norethisterone. The haemoglobin value changed from7.27 to 8.32 at two months, 8.7 at the end of four months and 8.99 at the end of six months in case of Ormeloxifene reflecting an increase of 14.44\% at two months. $19.67 \%$ at four months and $23.66 \%$ at six months. During the same period the rise in haemoglobin for Norethisterone group was $4.18 \%$ at two months, $7.68 \%$ at four months and $12.26 \%$ at six months.

\begin{tabular}{|lrrrr|}
\multicolumn{5}{|c}{ Test Statistics - Haemoglobin level } \\
\hline & $\begin{array}{l}\text { Pre- } \\
\text { treatment }\end{array}$ & $\begin{array}{l}\text { After 2 } \\
\text { Months }\end{array}$ & $\begin{array}{l}\text { After 4 } \\
\text { Months }\end{array}$ & $\begin{array}{l}\text { After 6 } \\
\text { Months }\end{array}$ \\
\hline $\begin{array}{l}\text { Mann- } \\
\text { Whitney U }\end{array}$ & 809.5 & 914.5 & 954.5 & 898.5 \\
\hline Z & -2.911 & -2.315 & -2.039 & -2.427 \\
\hline $\begin{array}{l}\text { Exact Sig. (2- } \\
\text { tailed) }\end{array}$ & 0.656 & 0.02 & 0.043 & 0.013 \\
\hline
\end{tabular}

\begin{tabular}{|lcccr|}
\hline & $\begin{array}{l}\text { Pre- } \\
\text { treatment }\end{array}$ & $\begin{array}{l}\text { After 2 } \\
\text { Months }\end{array}$ & $\begin{array}{l}\text { After 4 } \\
\text { Months }\end{array}$ & $\begin{array}{l}\text { After 6 } \\
\text { Months }\end{array}$ \\
\hline Ormeloxifene & 7.27 & 8.32 & 8.7 & 8.99 \\
\hline \%Change & & $14.44 \%$ & $19.67 \%$ & $23.66 \%$ \\
\hline Norethisterone & 7.42 & 7.73 & 7.99 & 8.33 \\
\hline \% Change & & $4.18 \%$ & $7.68 \%$ & $12.26 \%$ \\
\hline
\end{tabular}

Table-3 Average Haemoglobin levels of the two groups 
The difference between the two groups was statistically significant at the end of the treatment. Ormeloxifene was thus better than Norethisterone in terms of rise in amount of haemoglobin.

Menstrual blood loss was assessed in patients undergoing treatment under the study using a pictorial blood assessment chart. The initial average PBAC score for Ormeloxifene group was 196.46 and that of Norethisterone was 186.35. The PBAC scoring changed from an average of 196.46 at first visit to 155.76 at two months; 111.26 at four months and 79.57 at end of six months in case of Ormeloxifene leading to a decrease of $20.72 \%$ at two months, $43.37 \%$ at four months and $59.50 \%$ at six months. In the Norethisterone group the value changed from 186.35 initially to 150.36 at two months; 129.06 at four months and 105.76 at six months. The decrease in the score was $19.31 \%$ at two months, $30.74 \%$ at four months and $43.25 \%$ at six months.

\begin{tabular}{|c|c|c|c|c|}
\hline & $\begin{array}{l}\text { Pre- } \\
\text { treatment }\end{array}$ & $\begin{array}{l}\text { After } 2 \\
\text { Months }\end{array}$ & $\begin{array}{l}\text { After } 4 \\
\text { Months }\end{array}$ & $\begin{array}{l}\text { After } 6 \\
\text { Months }\end{array}$ \\
\hline $\begin{array}{l}\text { Mann- } \\
\text { Whitney U }\end{array}$ & 417.00 & 548.50 & 646.50 & 1019.50 \\
\hline Z & -5.746 & -4.839 & -4.165 & -1.440 \\
\hline $\begin{array}{l}\text { Exact Sig. (2- } \\
\text { tailed) }\end{array}$ & .131 & .045 & .032 & .011 \\
\hline
\end{tabular}

Table-4 Mann-Whitney U test result for PBAC

\begin{tabular}{|lcccc|}
\hline & $\begin{array}{c}\text { Pre-treatment } \\
\text { Ormeloxifene }\end{array}$ & $\begin{array}{c}\text { After } \\
\text { Months }\end{array}$ & $\begin{array}{c}\text { After } \\
\text { Months }\end{array}$ & $\begin{array}{c}\text { After 6 } \\
\text { Months }\end{array}$ \\
\hline \%Change & 196.46 & 155.76 & 111.26 & 79.57 \\
\hline Norethisterone & 186.35 & 150.36 & 129.06 & 105.76 \\
\hline \%Change & & $19.31 \%$ & $30.74 \%$ & $43.25 \%$ \\
\hline
\end{tabular}

Table-5 Average PBAC of the two groups

The application of tests of significance are tabulated above and show that though bleeding decreased in both the groups the results were better in case of Ormeloxifene with a p value of 0.032 and 0.011 at four months and six months of treatment.

Test Statistics - Endometrial thickness

\begin{tabular}{|lrr|}
\hline & Pre-treatment & \multicolumn{1}{l|}{ After 4 Months } \\
\hline $\begin{array}{l}\text { Mann-Whitney } \\
\text { U }\end{array}$ & 1142.00 & 794.50 \\
\hline $\mathrm{Z}$ & -0.746 & -2.758 \\
\hline $\begin{array}{l}\text { Exact Sig. (2- } \\
\text { tailed) }\end{array}$ & 0.012 & .005 \\
\hline
\end{tabular}

Table-6 Mann-Whitney U test result for endometrial thickness

\begin{tabular}{|lrrr|}
\hline & \multicolumn{1}{l}{$\begin{array}{l}\text { Pre- } \\
\text { treatment }\end{array}$} & \multicolumn{1}{c|}{$\begin{array}{l}\text { After 4 } \\
\text { Months }\end{array}$} & \multicolumn{2}{l}{$\begin{array}{l}\text { \% decrement } \\
\text { in ET }\end{array}$} \\
\hline Ormeloxifene & 5.49 & 4.49 & $18.25 \%$ \\
\hline Norethisterone & 5.08 & 4.83 & $5.08 \%$ \\
\hline
\end{tabular}

Table-7 Average endometrial thickness of the two groups

The initial average endometrial thickness was 5.49 and 5.08 in the two groups. The endometrial thickness changed to 4.49 in case of Ormeloxifene and 4.83 in case of Norethisterone showing a significant decrease in the former compared to late rand and the inter group variation was significant.

The patients were questioned on a five point Likert Questionnaire so as to assess the subjective improvement during the course of treatment. The patients were questioned about general health, amount of flooding, abdominal pain and degree of limitation of social and sexual activity and were scored on a scale of one to five. The analysis of the subjective improvement showed that patients using ormeloxifene were more satisfied compared to norethisterone.

There was no incidence of breakthrough bleeding in case of Ormeloxifene while there were seven such episodes in the Norethisterone group. Patients on Norethisterone complained of spotting in four cases. 
Statistics - Side Effects

\begin{tabular}{|c|c|c|c|c|c|c|c|}
\hline & & $\begin{array}{l}\text { Missing } \\
\text { Data }\end{array}$ & $\begin{array}{l}\text { No } \\
\text { Improvement }\end{array}$ & $\begin{array}{l}\text { Below } \\
\text { Average } \\
\text { Improvement }\end{array}$ & $\begin{array}{l}\text { Average } \\
\text { Improvement }\end{array}$ & $\begin{array}{l}\text { Considerable } \\
\text { Improvement }\end{array}$ & $\begin{array}{l}\text { Outstanding } \\
\text { Improvement }\end{array}$ \\
\hline \multirow{2}{*}{$\begin{array}{l}\text { General } \\
\text { health }\end{array}$} & Ormeloxifene & 5 & 1 & 3 & 5 & 17 & 19 \\
\hline & Norethisterone & 7 & 2 & 7 & 5 & 8 & 21 \\
\hline \multirow{2}{*}{$\begin{array}{l}\text { Amount of } \\
\text { flooding }\end{array}$} & Ormeloxifene & 5 & 5 & 0 & 8 & 6 & 26 \\
\hline & Norethisterone & 7 & 6 & 5 & 3 & 12 & 17 \\
\hline \multirow{2}{*}{$\begin{array}{l}\text { Abdominal } \\
\text { pain }\end{array}$} & Ormeloxifene & 5 & 2 & 3 & 8 & 4 & 28 \\
\hline & Norethisterone & 7 & 5 & 5 & 3 & 15 & 15 \\
\hline \multirow{2}{*}{$\begin{array}{l}\text { Degree of } \\
\text { limitation of } \\
\text { social } \\
\text { activity }\end{array}$} & Ormeloxifene & 5 & 2 & 2 & 4 & 12 & 25 \\
\hline & Norethisterone & 7 & 3 & 6 & 4 & 7 & 23 \\
\hline \multirow{2}{*}{$\begin{array}{c}\text { Effect on } \\
\text { sexual } \\
\text { activity }\end{array}$} & Ormeloxifene & 5 & 1 & 3 & 5 & 10 & 26 \\
\hline & Norethisterone & 7 & 3 & 5 & 7 & 9 & 19 \\
\hline
\end{tabular}

\begin{tabular}{|lrr|}
\hline Side Effects & Ormeloxifene & \multicolumn{1}{l}{ Norethisterone } \\
\hline No side effects & $21(42 \%)$ & $13(26 \%)$ \\
\hline Nausea & $10(20 \%)$ & $12(24 \%)$ \\
\hline Abdominal Pain & $8(16 \%)$ & $8(16 \%)$ \\
\hline Ovarian Cyst & $6(12 \%)$ & $0(0 \%)$ \\
\hline $\begin{array}{l}\text { White } \\
\text { Discharge/Cervical }\end{array}$ & $7(14 \%)$ & $5(10 \%)$ \\
\hline Amenorrhoea & $4(8 \%)$ & $0(0 \%)$ \\
\hline Hypo-menorrhoea & $5(10 \%)$ & $2(4 \%)$ \\
\hline Headache & $1(2 \%)$ & $2(4 \%)$ \\
\hline $\begin{array}{l}\text { Breakthrough } \\
\text { Bleeding }\end{array}$ & $0(0 \%)$ & $7(14 \%)$ \\
\hline Spotting & $0(0 \%)$ & $4(8 \%)$ \\
\hline
\end{tabular}

Table 8-Side Effects observed for both the groups

Table 9- Subjective improvement observed for both the groups

After analyzing the subjective improvement in SPSS, it was found that the $\mathrm{p}$ value to be .043 . Hence we can reject the null hypothesis and can say that there was subjective improvement in ormeloxifene group compared to norethisterone.

\section{Discussion}

Norethisterone is currently listed on the WHO list of essential medicine as a drug for contraception, dysfunctional uterine bleeding and hormonal replacement therapy. The reviewed studies found that Norethisterone significantly reduced menstrual blood loss but it was less effective than danazol, tranexamic acid, NSAIDS and levonorgestrel releasing intrauterine devices. It is still the most frequently prescribed drug for dysfunctional uterine bleeding serving $38 \%$ of the patient population the reason being cost effectiveness and absence of side effects.

Ormeloxifene may be offered as a treatment option for dysfunctional uterine bleeding at a dose 60mg. The drug offers contraceptive benefit and in the same sitting has a convenient twice a week schedule and is cost effective as well. The drug is yet to gain popularity in the arena of management of dysfunctional uterine bleeding.

Studies on the use of Ormeloxifene for DUB are limited. Kriplani et al showed a significant decrease in menstrual blood loss after two months and four months $(\mathrm{p}<0.05)$. After discontinuation of the drug bleeding decreased but was still lower than pre-treatment value. The results were in agreement to our study. The side effects observed in their study included ovarian cyst (7.1\%), gastric upset (7.1\%), vague abdominal pain (4.8\%) and headache (4.8\%). We observed 6 cases of ovarian cyst (12\%) in our study. Other side effects were similar to their study.

The results of the present study are comparable to study by Biswas et al. The median difference in pretreatment and post treatment menstrual blood loss was statistically significant $(\mathrm{p}<0.001)$. The pre-treatment and post treatment haemoglobin values was also significant.

Bhattacharyya et al compared Ormeloxifene Norethisterone and iron in treatment of DUB. They concluded that both Ormeloxifene and Norethisterone significantly reduce blood loss in patients of dysfunctional uterine 
bleeding. Ormeloxifene was found to be superior to Norethisterone in reducing menstrual blood loss. The side effects stress urinary incontinence and genital prolapsed were not encountered in our study. The other results were similar to our study.

Though conclusions from the study are limited by small number of subjects, finding confirm the clinical efficacy of ormeloxifene in dysfunctional uterine bleeding. The findings also suggest that ormeloxifene is more effective than norethisterone. Norethisterone is widely used and studies for detailed assessment of its efficacy and safety in comparison of ormeloxifene are due. If findings of this study are further confirmed ormeloxifene could be used as a first line therapy for dysfunctional uterine bleeding.

\section{Conclusion}

The menstrual blood loss was observed to decrease by $19.31 \%$ at end of two months, $30.74 \%$ at the end of four months and $43.25 \%$ at end of six months in case of norethisterone and $20.72 \%$ at the end of two months, $43.37 \%$ at end of four months and $59.50 \%$ at the end of six months in case of Ormeloxifene.

There was an increase in haemoglobin percentage in both the groups and it was significantly better in case of Ormeloxifene. Also in PBAC score and endometrial thickness improvement was observed better in case of ormeloxifene compared to norethisterone. The subjective improvement was measured using Likert scale and found to be significantly better in case of ormeloxifene compared to norethisterone group.

The side effects were similar in both the cases except for follicular cyst which was seen in Ormeloxifene group only and breakthrough bleeding which was seen in Norethisterone group only.

We thus conclude that ormeloxifene is a better option compared to norethisterone in treatment of dysfunctional uterine bleeding.

\section{References}

[1]. Indian Journal of Clinical Practice (2001): (12), 2, 31-34: Evecare syrup in dysfunctional uterine bleeding.

[2]. Kriplani A, Kulshrestha V, AgarwalN. "The efficacy and safety of ormeloxifene in the management of menorrhagia: a pilot study". J. Obstet. Gynaecol 2009; 35 (4): 746-52.

[3]. Biswas SC, Saha SK, et al.ormeloxifene a selective estrogen receptor modulator, for the treatment of DUB .J ObstetGynaecol Ind:2004:54(1):56-59.

[4]. Higham et al, (1990), Assessment of menstrual blood loss using a pictorial chart, British Journal of Obstetrics \& Gynaecology, 97, pp734-739.

[5]. Bhattacharyya, Tapan Kumar; Banerji, Anusyuaetal :Efficacy of a Selective Estrogen Receptor Modulator: 'Ormeloxifene' in Management of Dysfunctional Uterine Bleeding : Journal of South Asian Federation of Obstetrics \& Gynecology;Sep-Dec2010, Vol. 2 Issue 3, p207.

[6]. Hysterectomy in the United States, 2000-2004: Division of Reproductive Health, National Center for Chronic Disease Prevention and Health Promotion.

[7]. Abnormal Uterine Bleeding : JANET R. ALBERS, M.D., SHARON K. HULL, M.D., and ROBERT M. WESLEY, M.A., Southern Illinois University School of Medicine, Springfield, Illinois.

[8]. Abnormal Uterine Bleeding: JANET R. ALBERS, M.D., SHARON K. HULL, M.D., and ROBERT M. WESLEY, M.A., Southern Illinois University School of Medicine, Springfield, Illinois :Am Fam Physician. 2004 Apr 15; 69(8):1915-1926.

[9]. Hallberg L, Hogdahl A, Nilsson L, Rybo G. Menstrual blood loss: a population study .Variations at different ages and attempts to define normality. ActaObstetGynecolScand 1996; 45: 320-51.

[10]. Management of Dysfunctional Uterine Bleeding :Yovanni Casablanca: ObstetGynecolClin N Am 35 (2008) $219-234$.

[11]. Quinn M, Neale BJ, Fortune DW. Endometrial carcinoma in premenopausal women: a clinicopathological study. GynecolOncol 1985; 20:298-306.

[12]. Dysfunctional Uterine Bleeding BERTHA H. CHEN; MD, and LINDA C. GIUDICE, MD, PhD, Stanford, Califomia, West J Med 1998; 169:280-284.

[13]. Fraser IS, Hickey M, Song JY. A comparison of mechanisms underlying disturbances of bleeding caused by spontaneous dysfunctional uterine bleeding or hormonal contraception. Human Reprod 1996.

[14]. Smith SK, Abel MH, Kelly RW, Baird DT. Prostaglandin synthesis in the endometrium of women with ovular dysfunctional uterine bleeding. Br J ObstetGynaecol 1981; 88:434-442.

[15]. Lethaby A, Augood C, Duckitt K. Nonsteroidal anti-inflammatory drugs for heavy menstrual bleeding [Cochrane Review]. In: The Cochrane Library, Issue 2. Oxford: Update Software; 2001.

[16]. Cooke I, Lethaby A, Farquar C. Antifibrinolytics for heavy menstrual bleeding [Cochrane Review]. In: The Cochrane Library, Issue 2. Oxford: Update Software; 2001.

[17]. Fraser IS. Treatment of ovulatory and anovulatory dysfunctional uterine bleeding with oral progestogens. Aust $\mathrm{N} Z \mathrm{Z}$ ObstetGynaecol. 1990; 30:353-356.

[18]. Lethaby A, Irvine G, Cameron I.Cyclicalprogestogens for heavy menstrual bleeding [Cochrane Review]. In: The Cochrane Library, Issue 2. Oxford: Update Software; 2001.

[19]. Nilsson L, Rybo G. Treatment of menorrhagia. Am J Obstet Gynecol. 1971;110:713-720.

[20]. Zupi E, Zullo F, Marconi D, et al. Hysteroscopic endometrial resection versus laparoscopic supracervical hysterectomy for menorrhagia: A prospective randomized trial. Am J ObstetGynecol. 2003;188:7-12.

[21]. Thakar R, Ayers S, Clarkson P,Stanton S, Manyonda I. Outcomes after total versus subtotal abdominal hysterectomy. N Engl J Med. 2002; 347:1318-1325.

[22]. Learman LA, Summitt RL Jr, Varner RE, et al. A randomized comparison of total or supracervical hysterectomy: Surgical complications and clinical outcomes. Obstet Gynecol. 2003; 102:453-462.

[23]. Gurtcheff SE, Sharp HT. Complications associated with global endometrial ablation: The utility of the MAUDE database. Obstet Gynecol. 2003;102:1278-1282. 